\title{
Gardens in the Traditional Houses - A Study on the Garden Elements in the Traditional Houses of Trabzon, Turkey
}

\author{
Reyhan Akat ${ }^{1}$, Birgül Çakıroğlu²
}

\author{
${ }^{1}$ Ministry of environment and urban planning, Presidency for Strategy Development, Ankara, Turkey \\ ${ }^{2}$ Department of Construction and Technical Works, Karadeniz Technical University, 61080, Trabzon, Turkey
}

\begin{abstract}
The purpose of this study is to seek answers, and find solutions, to the following questions: How should the house-garden relationship be reinforced for a healthy and harmonic life? Can some criteria be determined for the design of the gardens? How can outer spaces be created consciously? This study examined the traditional houses and their gardens in Trabzon, the main focus being more on the gardens. Some of the peculiar characteristics of the garden houses were emphasized. The house-garden types were grouped and were shown schematically. Each element (gates, fountains, wells + fountains, wells, fireplaces) in gardens was explained in terms of house-garden relationship. The types of garden houses have been also studied from the point of view of the plants. To this end, this study investigates the garden-house and garden designs in traditional Trabzon houses that have come down to our present day, and presents data for the new present-day garden-house and garden designs to be made.
\end{abstract}

Keywords: Garden, Garden-House Typologies, Historical Houses, Gardens, Plants, Garden Elements (gates, fountains, wells, fireplaces), Green Areas, Traditional Housing, Cloister

\section{INTRODUCTION}

As a result of the negative effects that started with urbanization and that, in a sense, changed and harmed the urban texture, city clarity has been in a process of diminution and the notion of "continuity from the past to the future" in the cities has been disappearing. Discovering the products of the past and the environments where they were created will make it easy to find a bright way especially for the future.

Utilizing the nature and especially the open green spaces which are part of the nature is a very important need for the modern human being. Buildings that the city, and therefore the human being, needs are not solely buildings, which is a physical fact; they are at the same time different spaces or spatial elements. One such space is the garden of a house as an open green space which meets different needs (Sağsöz \& Gedikli 1999).

Today, the conservation and improvement of the open green spaces in the cities are becoming more and more important. Research has shown that human beings who are distressed by the negative conditions created by the the urban haste find physical and psychological peace, become stronger and become filled with a will to live (Syme \& Fenton 2001; Egoz \& Bowring 2004; Gedikli \& Özbilen 2004; Thwaites et al. 2005; Tzoulas et al. 2007; Barbosa et al. 2007; Kim et al. 2008; Cavia \& Cueto 2009). By providing more sunlight, more clean air and more opportunity for free movement, urban open spaces make human beings, and therefore the society, healthier, and create a more balanced, a more refreshing and a more useful environment (Westover 1989; Simonds 1994; Hillman 1994; Ribe 2005; Colding 2007; Swensen \& Jerpasen 2008; Yang et al. 2009).

The character of a city is determined by the spaces and elements in that city. The most important ones of these are our houses and their close vicinities (Yang \& Brown 1982; Burel \& Baudry 1995; Bhatti \& Church 2004; Syme et al. 2004; Freestone \& Nichols 2004; Rogge et al.2007). Plants have an important place in the formation of the close vicinities of the houses (Kalın A, Gedikli R, Pulatkan M, Acar C 1999). A continuity (from the past to the future) is obtained with the use of plants with historical accumulation for various purposes. This contributes to the formation of the character of a city (Jim 1998; Gedikli \& Çakıroğlu 2003; Ong 2003; Walsh 2008).

This article is published under the terms of the Creative Commons Attribution License 4.0 Author(s) retain the copyright of this article. Publication rights with Alkhaer Publications.

Published at: http://www.ijsciences.com/pub/issue/2017-10/

DOI: 10.18483/ijSci.1385; Online ISSN: 2305-3925; Print ISSN: 2410-4477 
Since the prehistoric times, garden house designs and ways of living in such spaces and therefore the elements and ornamental flowers used have been in a continuous evolution, and they have been interpreted differently in different cultures (Bhatti \& Church 2000; Kenneth 2007; Janssen \& Knippenberg 2008; Taylor 2009). Societies with different cultures and traditions, in short, societies with different ways of living have had different garden house designs (Antrop 2004; Van Eetvelde et al. 2004; Turner 2006; He \& Jia 2007; Vileniske 2008; Perry \& Nawaz 2008; Jim \& Chen 2009). For, even though the basic needs are the same for all human beings, the activities that these needs require, the relationships among these activities, and the relationships between these activities and the spaces differ according to the way of living of each society, and this difference affects the formation of the structural environmental elements and the use of plants (Pol et al. 2002; Ryan 2005).

Throughout the history, we see a continuous relationship between human beings and plants in the formation of the close vicinity of the house. At one end of this relationship are the functionality/utility, aesthetic attractiveness, fruit attractiveness and flower attractiveness as the characteristics of use, while at the other end are their cultural values which identify and integrate with the historical environment. The plants with historical and cultural values in the gardens of the traditional houses that have come down to the present day have been in a process of gradual disappearance (Dincyurek 2003).

The traditional garden house designs have also been different. The traditional Turkish house is closed to the outside, it is surrounded by walls, and the ornamental plants extend over to the street, which are a reflection of the social structure and which give a definite form to the house.

The conception of garden design that was developed in the traditional Turkish houses under the impact of socio-cultural factors has affected the plant types used, and the formation and originality of the houses. This is so much so that some traditional plants are virtually identified with the people of that area.

For this study, Ortahisar and Pazarkap1 neighborhoods, which are two of the protected areas in Trabzon, were chosen as the field of work.

This study attempts to identify the plants which have traditional characteristics and which are about to disappear in the gardens of the traditional houses which have historical and cultural values and which are under protection. It also attempts to find ways of improving the existing states of the existing plants, and of keeping them alive during the restoration works of the buildings, or to identify the plants that are about to disapper and even the ones that have already disappeared. The study makes recommendations to grow, if possible, the same or similar plants in greenhouses. The study also presents data about the restoration works related to the reintroduction of the historical plants in the gardens of the traditional houses. This study attempted to identify some of the peculiar characteristics of the garden houses bearing in mind that this would be useful for the prospective studies in the fields of architecture and landscape architecture.

This study identified the plant types used in the traditional garden houses classified the plants according to their use (aesthetic attractiveness, functionality, etc.), and questioned whether it is possible to use them in the present day.

\section{MATERIALS AND METHODS}

\section{Field of Work-Sample selection}

For this study, the traditional garden houses in two protected areas (Ortahisar and Pazarkap1 neighborhoods) in the city of Trabzon ,Turkey in the Eastern Black Sea Region were chosen as the field of work (Figure

$1)$.
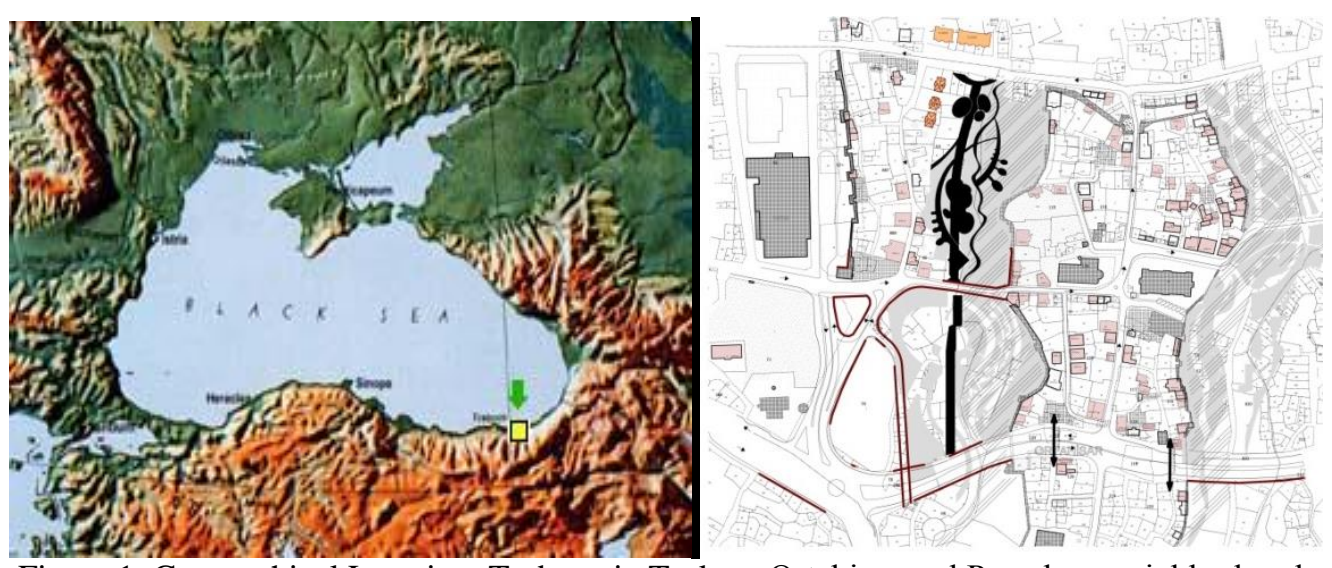

Figure 1. Geographical Location, Trabzon in Turkey- Ortahisar and Pazarkapı neighborhoods 


\section{Methods}

For the study, the original designs of the traditional garden houses were determined, and based on the existing houses, their general characteristics were identified. The plants with historical-cultural value were classified according to their types; and the reasons for their use were determined (Figure 2, Figure 3).

Naturally, the houses which were studied have had a transformation process and consequently have been exposed to some changes, both physically and socially. The changing ways of living and the changing users and the accompanying redesigns and additions are reflected in the garden, and therefore the original form of the garden has been changed. Among the available samples, few have come down to the present day intact. Bearing all these in mind, the study tried to expose the original forms of the gardens based mainly on the sources (literature review and the old house owners), and classified the house-garden typologies and plants according to their types.

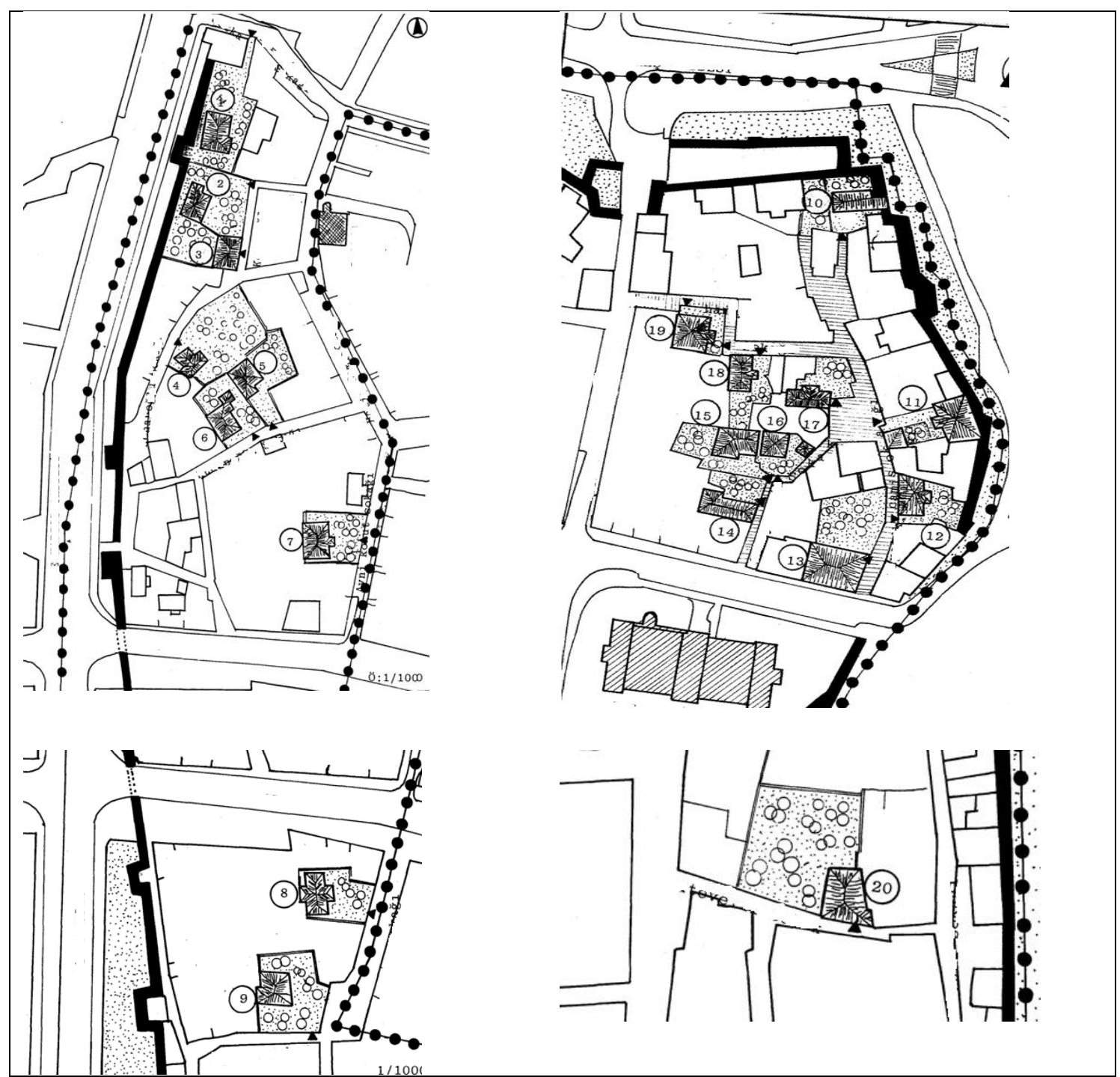

Figure 2. The traditional garden houses in two protected areas, Ortahisar and Pazarkap1 Neighborhoods 


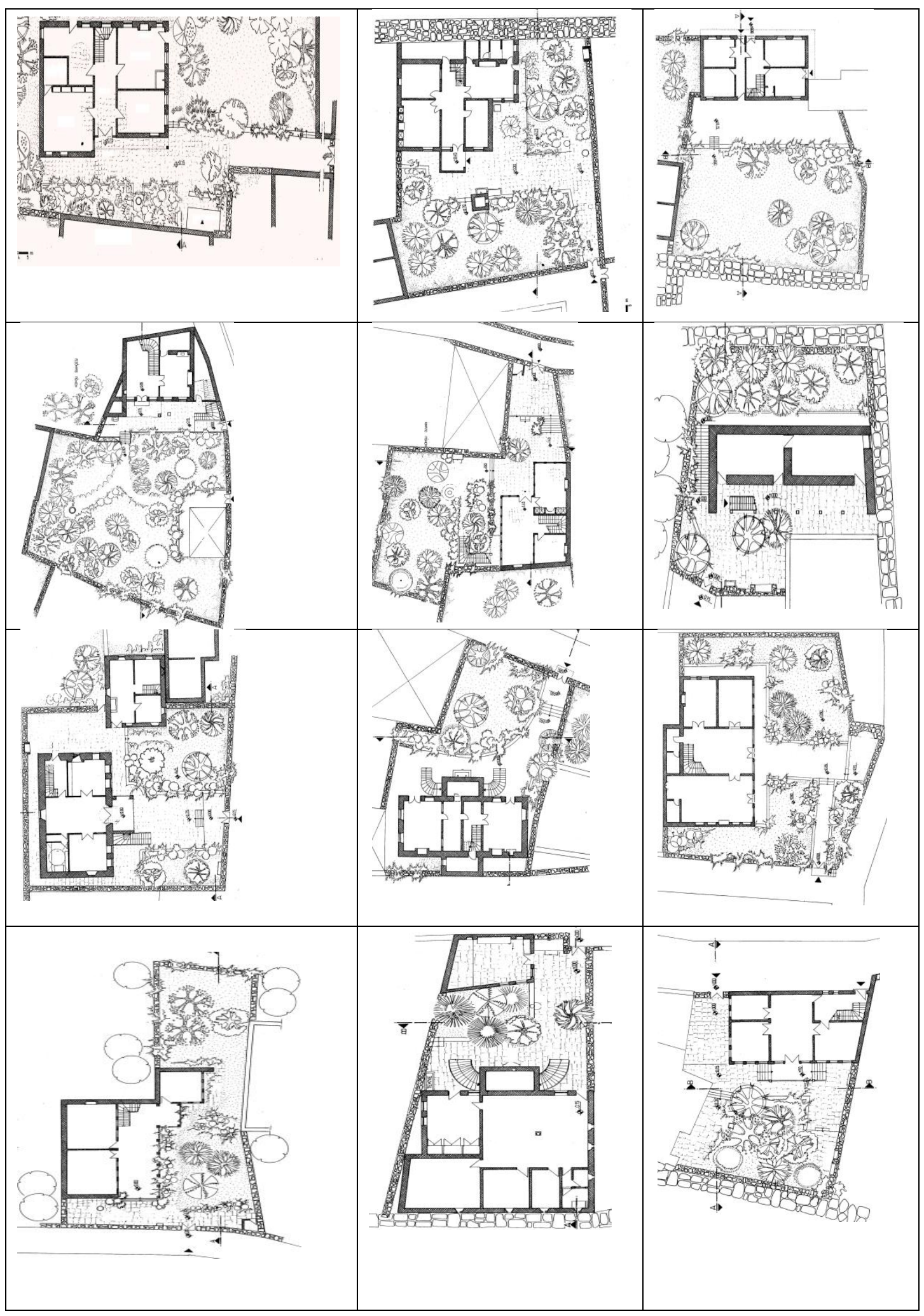

Figure 3. The original designs of the traditional garden houses

\section{RESULTS}

Typological Works at the Houses

Depending on the locations of the houses on the land, the various house-garden types were identified as follows: (Table 1, Table 2, Table 3).
.Houses with gardens on four sides,

.Houses with front and back gardens,

.Houses adjacent to the street walls,

.Houses with front gardens,

.Houses with front and side gardens, 
.Houses with side and back gardens,

.Houses with back gardens,

.Houses adjacent to two back walls,

.Houses with front and side gardens,

.Houses adjacent to the back walls,

.Houses with front gardens.

In general, the house types that were identified are as follows:

At the first level (the most common type)

.Houses adjacent to the street walls with front and side gardens,

.Houses with front and side gardens with two adjacent back walls,
At the second level (second most common type)

.Houses adjacent to the street walls with front gardens, gardens,

.Houses adjacent to the back walls with front

At the third level (third most common type)

.Houses with gardens on four sides,

.Houses with front and back gardens,

.Houses adjacent to the street walls,

.Houses with back gardens,

.Houses with side and back gardens.

Table 1. Diagrams of garden-house types

\begin{tabular}{|c|c|c|}
\hline Types & Diagrams of ga & e types \\
\hline A & & Houses with gardens on all sides \\
\hline B & & Houses with front and back gardens \\
\hline $\mathrm{C} 1$ & & $\begin{array}{l}\text { Houses adjacent to the street walls with front and } \\
\text { back gardens }\end{array}$ \\
\hline $\mathrm{C} 2$ & & $\begin{array}{l}\text { Houses adjacent to the street walls with front and } \\
\text { side gardens }\end{array}$ \\
\hline C3 & & $\begin{array}{l}\text { Houses adjacent to the street walls with side and } \\
\text { back gardens }\end{array}$ \\
\hline C4 & & $\begin{array}{l}\text { Houses adjacent to the street walls with back } \\
\text { gardens }\end{array}$ \\
\hline
\end{tabular}




\begin{tabular}{|l|l|l|}
\hline $\mathrm{D}$ & $\begin{array}{l}\text { Houses adjacent to two back walls with front and } \\
\text { side gardens }\end{array}$ \\
\hline $\mathrm{E}$ & & $\begin{array}{l}\text { Houses adjacent to the back walls with front } \\
\text { gardens }\end{array}$ \\
\hline
\end{tabular}

Table 2. Diagrams of garden house entrance types

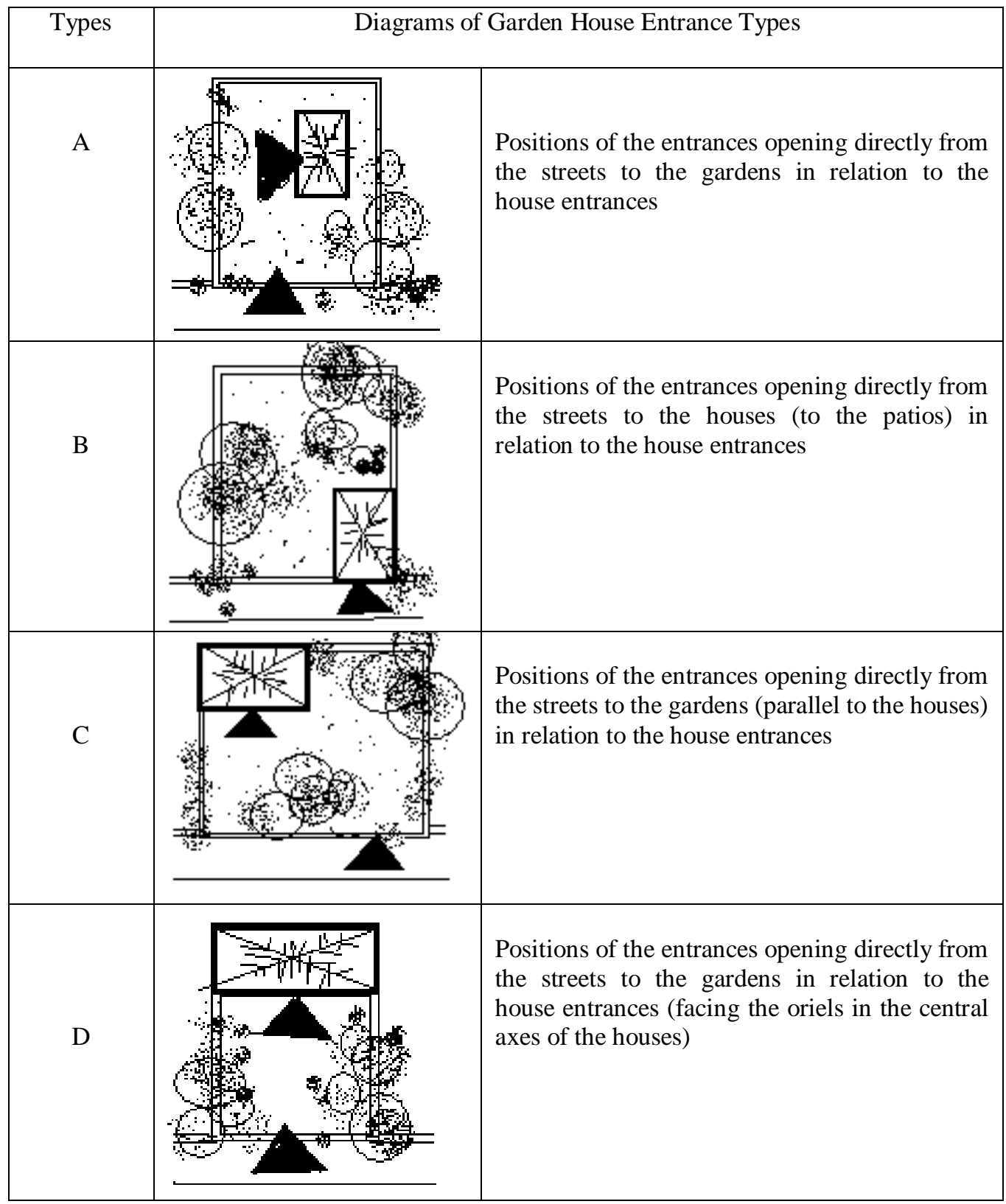


Table 3. Elements in the gardens of the houses

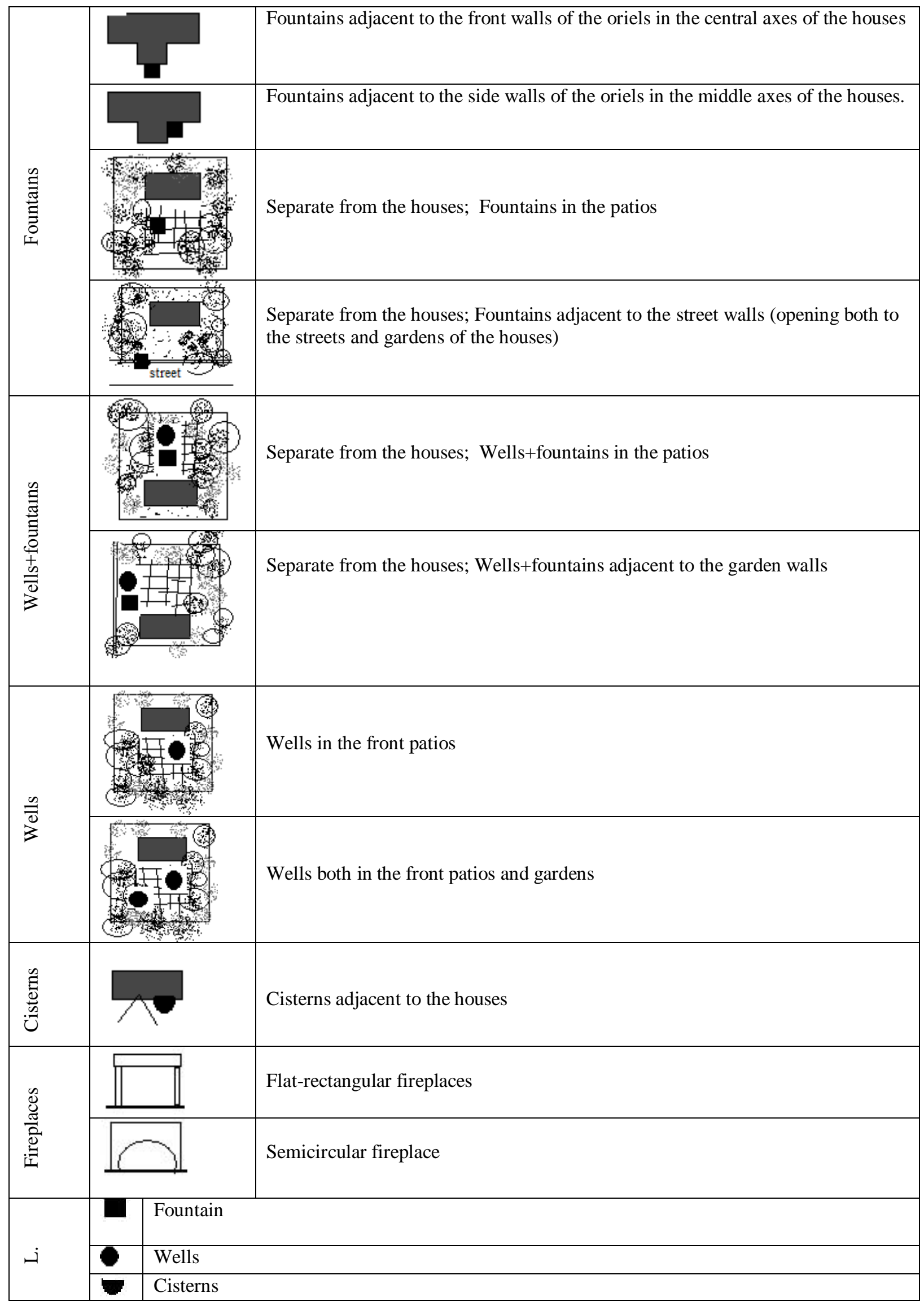


According to the data that were obtained, houses with front gardens are the most common, and houses with back gardens and houses with gardens on all sides are the least common (Gedikli R 1992).

\section{Garden Elements}

Garden elements were studied as: gates, fountains, wells+fountains, wells, fireplaces and plants.

\section{Gates}

The gates were grouped according to their locations and then they were classified as follows: (Table 3).

Gates that directly open from the street to the house, .Gates that open to the patios (in houses with exterior sofas),

.Gates that directly open from the street to the garden,

.Gates that face the second gates under the oriels in the center axes of the houses,

.Gates that open from the street wall to the garden and that are parallel to the house,

Gates adjacent to the house.

Gates are usually two-leafed and are made of wood. The ornamental elements on the gates are wrought nails, door handles, and knockers, which all have separate functions.

\section{Fountains}

Like other element, fountains were classified according to their locations (Table 3);

.Fountains adjacent to the house,

.Fountains adjacent to the front walls of the oriels in the middle axis of the house,

.Fountains adjacent to the side walls of the oriels in the middle axis of the house (Such fountains were usually found in traditional Greek house gardens),

.Fountains separate from the house,

.Fountains in the patio,

.Fountains adjacent to the street wall (such fountains open to both the street and garden) (Fountains that are not adjacent to the houses are usually seen in the gardens of traditional Turkish houses and in the gardens of hybrid houses).

\section{Wells + fountains}

According to their locations, wells+fountains were found to have the following types:

.Wells+fountains separate from the house, .wells+fountains in the patios, (Table 3). .wells+fountains adjacent to the garden walls

\section{Wells}

Like other elements, wells were also classified according to their locations.

.Wells in the patios in front of the houses,

.Wells both in the patios and courtyard (Table 3 ).

\section{Fireplaces}

Fireplaces were classified in terms of their forms as:

.Flat-rectangular fireplaces,

.Semicircular (arched) fireplaces (Table 3).

All house gardens contain mostly a combination of fountain, cistern, well, fireplace, laundry, and depot.

\section{Plants}

In general, Trabzon and its vicinities are a closed coastal strip. This coastal strip which is surrounded by mountains has a year-long mild and rainy climate. Due to the climatic conditions, the city and its environs have a rich flora.

It was found that the gardens are formed according to personal likes. The gardens contain various fruit trees and ornamental plants that are peculiar to the region. Of the fruit trees, cherry-laurel prunus laurocerasus L. which is peculiar to the Eastern Black Sea Region and which is very popular among the people in the region is identified with the region. In addition, Japanese persimmon is very popular in the region and is commonly used in the traditional houses (and therefore is called as 'Trabzon persimmon' in the region); however, it began to disappear and it is one of the vegetal elements that must be preserved.

Various vegetables are raised under the trees to meet the needs of the households. Purple wisteria and oleanders, etc. extend over to the streets from the garden walls. Various types of ivy complement the green of the streets. Gardens are more of utility gardens, and the trees are usually chosen from among the types whose fruits, flowers and leaves can be utilized.

The most common tree and shrub types in the gardens are shown in Figure 4.

The most common tree and shrub types;

Eriobotrya japonica (Japanese plum)

55,0\%,

Prunus domestical (plum)

$70,0 \%$,

Punica granatum (Pomegranate) 45,0\%,

Picus carica (Fig)

$45,0 \%$,

Citrus nobilis (Tangerine)

$45,0 \%$,

Aesthetic attractiveness is the major concern for the bushes and perennial plants. The most commonly used bushes and perennials in the gardens are as follows (Figure 5):

Rosa hybrida (Rose)

$70,0 \%$,

Hedere helix (Ivy) 50,0\%,

Lonicea pericyclemum (Honeysuckle) $\quad 35,0 \%$,

Philadelphus coronarius (Citrus flower) 35,0\%,

Hydrangea macrophylla (hortensia (Hydrangea) $30,0 \%$. 
As seen above, rosa ssp (rose) is the most common plant of bush type.

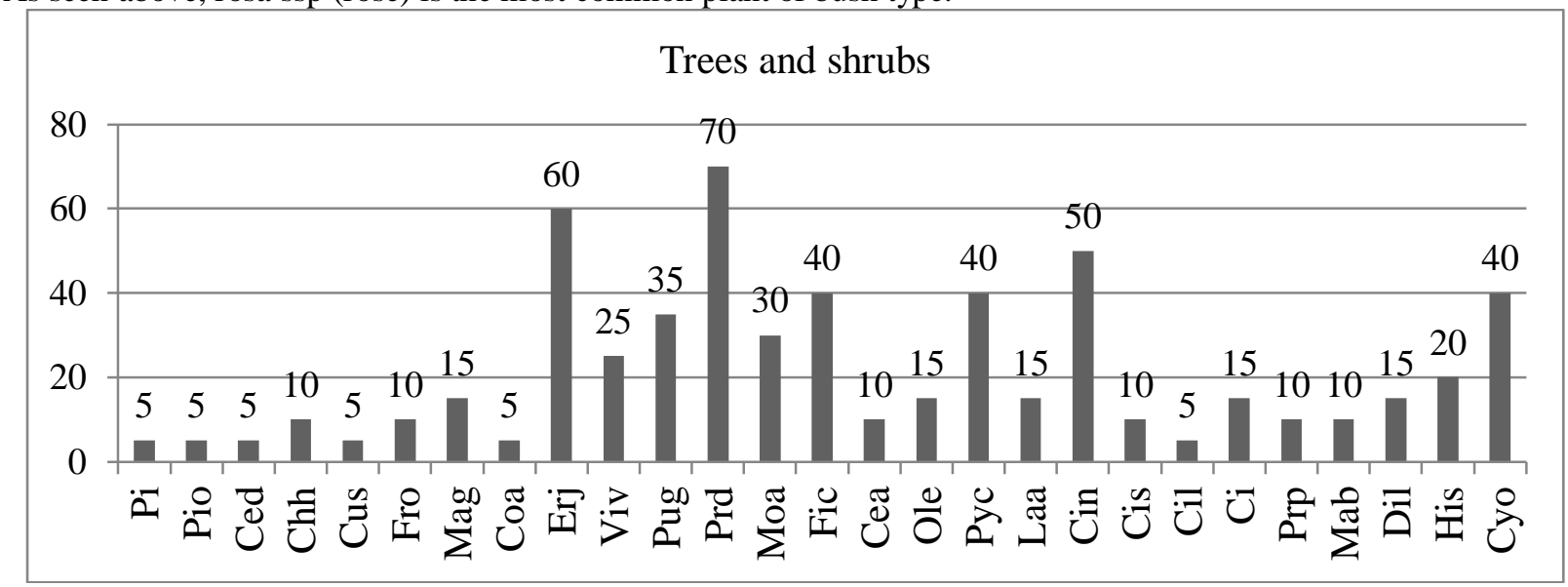

Figure 4. The use of plants: Trees and shrubs

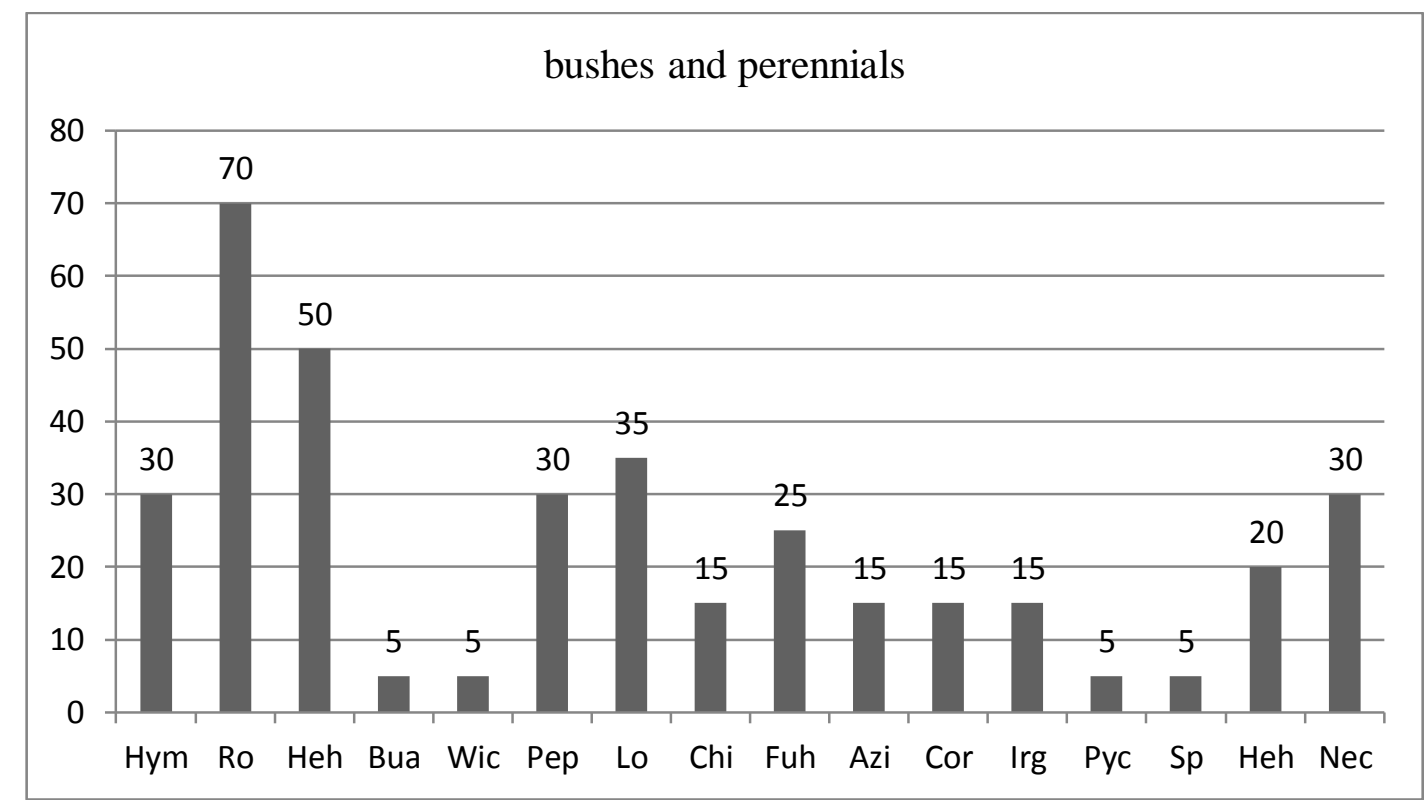

Figure 5. The use of plants: Bushes and perennials

The reasons for the use of the trees and shrubs in the gardens of the traditional houses are classified in Table 4:

.Utility (from fruits) $65,5 \%$

.Aesthetic attractiveness

.Fruit attractiveness $\quad 44,8 \%$,

.Flower attractiveness $\quad 34,5 \%$.

The plant types that have functional uses in the gardens are rather few.

There are no utilitarian purposes for the use of bushes and perennial plants. The main characteristic that is sought in such plants is flower attractiveness $(87,5 \%)$ (Table 4).
In the front gardens or in the immediate vicinities of the houses, aesthetic plants, especially types of bush with beautiful flowers are preferred. It was found that the back and side gardens are more of utility gardens, that they contain trees which yield fruits, and that vegetables are raised under the trees to meet the needs of the households (Tablo 5). The basic design principles (size, form, color, texture, balance, etc.) and the relationships between the plants and architectural elements were not taken into consideration when using different plants together. 
Table 4. Percentages of the use of plants in the gardens*

\begin{tabular}{|c|c|c|c|}
\hline \multicolumn{2}{|c|}{ The use of plants in the gardens } & $\begin{array}{l}\text { Percentages of the use of } \\
\text { trees and shrubs }(\%)\end{array}$ & $\begin{array}{l}\text { Percentages of the use of } \\
\text { bushes and perennials }(\%)\end{array}$ \\
\hline Functional & $\begin{array}{l}\text { View screening }(\mathrm{F} 2) \\
\text { Shadow element }(\mathrm{F} 3)\end{array}$ & $\begin{array}{l}10,3 \\
6,9\end{array}$ & 18,8 \\
\hline Aesthetic & $\begin{array}{l}\text { Color (E1) } \\
\text { Texture (E2) } \\
\text { Form (E3) } \\
\text { Flower attractiveness (E4) } \\
\text { Fruit attractiveness (E5) }\end{array}$ & $\begin{array}{l}17,2 \\
17,2 \\
34,5 \\
44,8\end{array}$ & 12,5 \\
\hline Utility & $\begin{array}{l}\text { Fruit (Y1) } \\
\text { Leaf (Y2) } \\
\text { Flower (Y3) }\end{array}$ & $\begin{array}{l}65,5 \\
6,9 \\
10,3\end{array}$ & \\
\hline
\end{tabular}

* The percentages of the use of plants in the gardens are weighted

\section{DISCUSSION}

The concept of garden is disappearing day by day. However, the benefits that gardens bring to both the users of the houses and external users cannot be ignored. For this reason, the need for the investigation of the examples which present us evidence about the house-garden designs both in the past and in the present day is apparent.

Bhatti M \& Church A (2004), stated that house and garden should be handled together and emphasized the garden culture. On the other hand, Yang B-E \& Brown TJ (1982) compared the traditional Korean and Japanese houses and gardens and identified the stylistic and cultural differences. Similarly, Missingham (2007), Janssen \& Knippenberg (2008), and Vileniske (2008) identified the effects of cultural differences, authenticity and cultural landscape design in the formation of houses and gardens. Ryan RL (2005), and Taylor (2009) studied the creation of arboretums in terms of the importance and sustainability of traditional landscape design and Pol E et al. (2002), and Hobson \& Louise D (2007) carried out studies on the importance of the traditional houses and gardens. Tzoulas $\mathrm{K}$ et al. (2007), Freestone R \& Nichols D (2004), Syme G J\& Fenton (2001), and Kim et al. (2008) emphasized the importance of green in the gardens of the houses in creating the urban ecosystem and showed that they need to be incorporated into green space system. Antrop M (2004) and Eetvelde V \& Antrop M (2004) explained the differences, evolution and development of landscape design in the traditional european culture. Jim CY (1998) and Egoz \& Bowring (2004) revealed the aesthetic and ecological contributions of the green on the traditional walls in the city to their environment and therefore to the city. On the other hand, He \& Jia (2007) found out that the socioeconomic and ecological factors affect the formation of the settlement areas.

This study investigated the houses-gardens-garden designs and the relationships among them in the traditional Trabzon houses, and presented data that can be used for new houses-gardens-garden designs.

It is necessary that the house-garden and house-street relationships be investigated and exposed. House and garden should be dealt with not individually but together bearing in mind the way of living of the society. This can only be achieved if house planning and garden planning are dealt with together.

The green and natural beauties should not be sacrificed unconsciously; monotonous spaces should be enlivened with green; and the inclusion of green designs in the spaces to be created should not be forgotten for both aesthetical concerns and for the harmonization of human beings with the environment.

The increase in the number of such studies which are more of an exploratory character is important in that they give us an opportunity to investigate and interpret what to make use of. The plant types which were once present in Trabzon but which are about to disappear today must be determined and used in the present-day designs.

Our traditional plants have started to disappear. However, in terms of the concerns of both culture and city health, their benefits cannot be underestimated. For this reason, it is apparent that the examples that provide us with data about the garden house designs both in the past and present should be investigated and preserved.

The plant types which were once present in Trabzon but which are very few today can be determined and used in the present-day designs.

It is important that the number of such studies that are more of an exploratory character be increased in that they give us an opportunity to investigate and interpret what to make use of. 
Table 5. The use of plants according to the garden house types

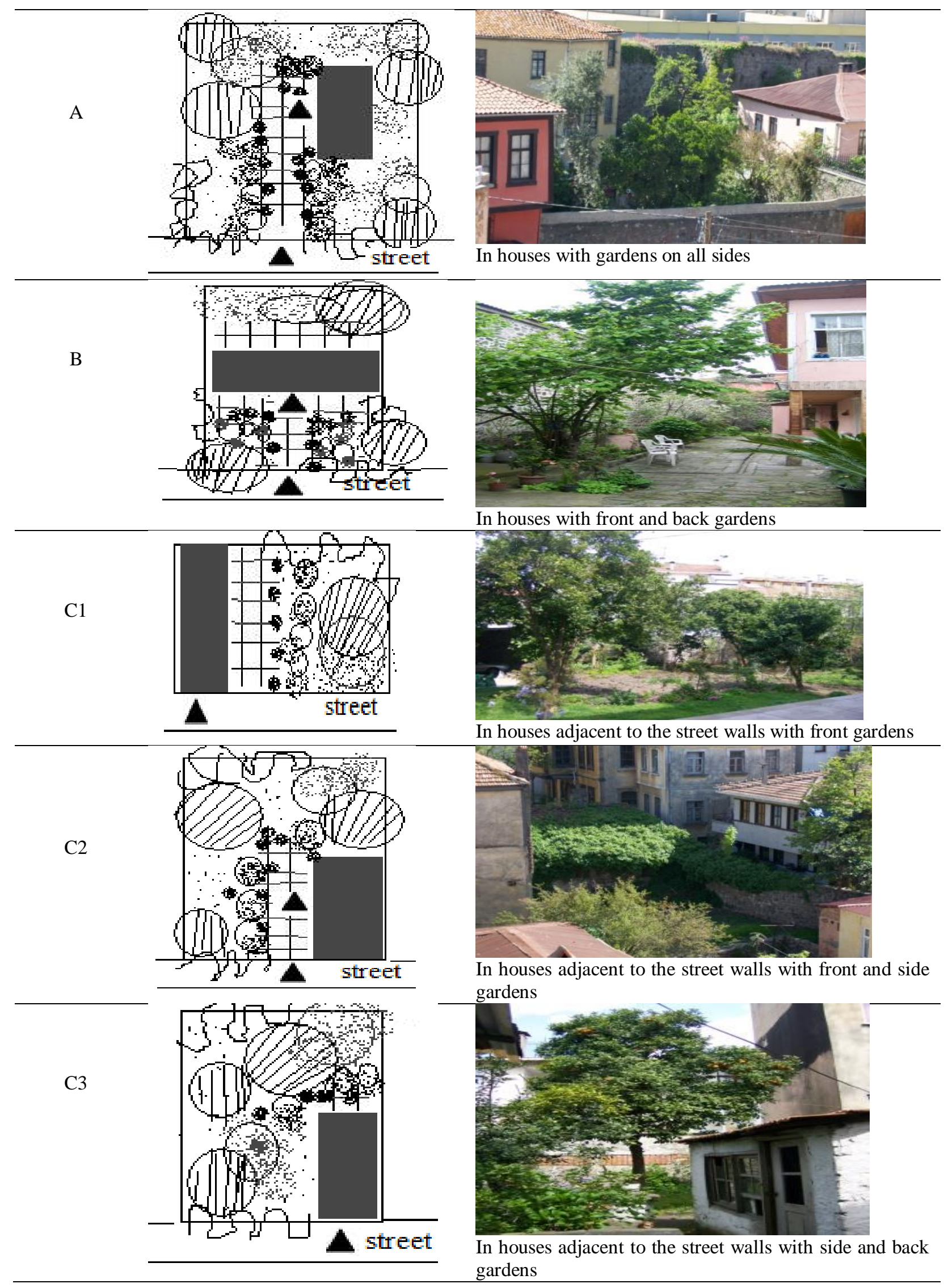




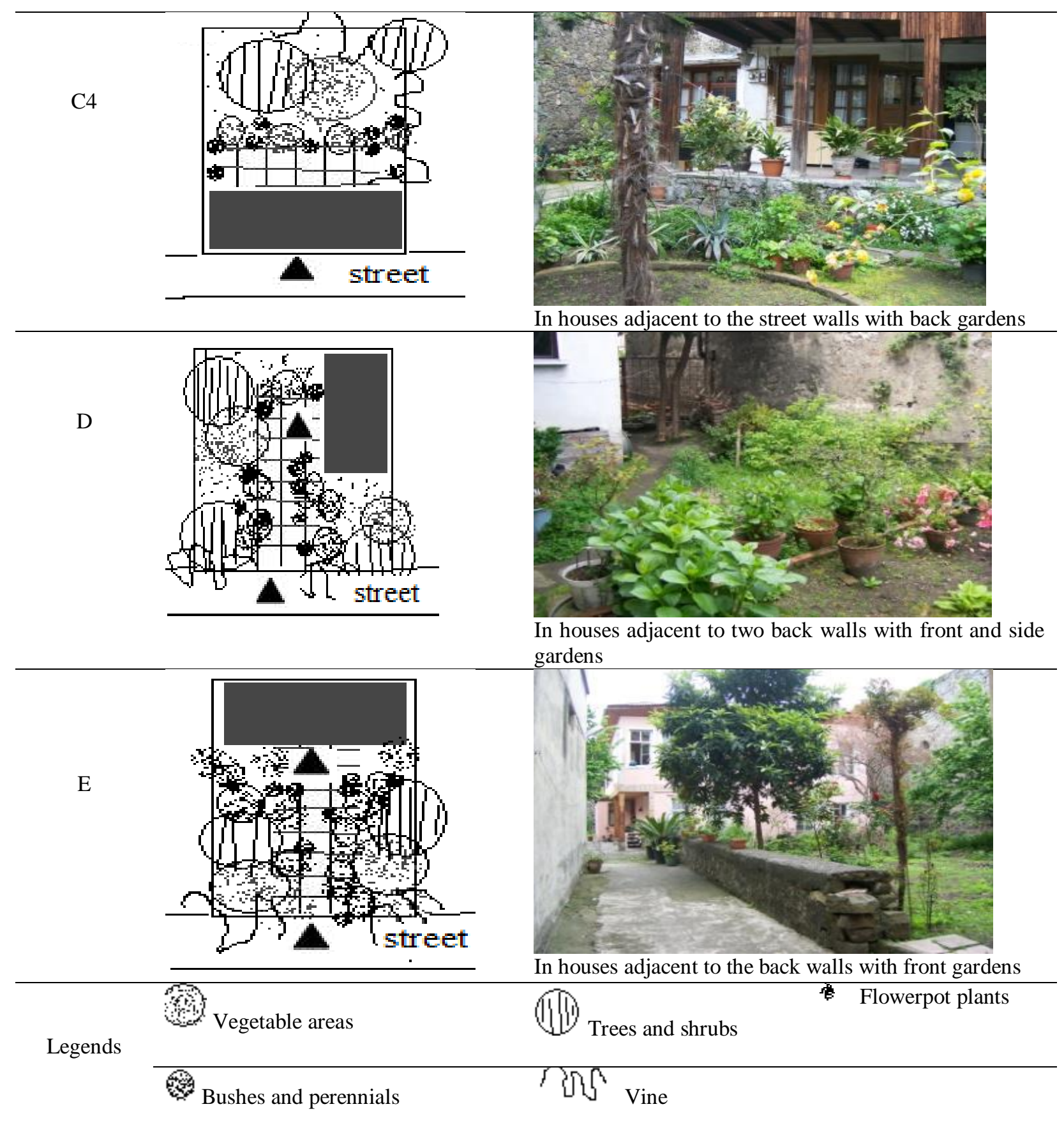

\section{References}

1. Sağsöz A \& Gedikli R 1999; Usage of green element as an increasing factor of visual quality in traditional home near environment, Our Visual Landscape Conference, 23-27 Auqust, Ascona, Switzerland.

2. Syme G.J, Fenton D.M, Coakes S 2001; Lot size, garden satisfaction and local park and wetland visitation, Landscape and Urban Planning, 56(3), pp.161-170.

3. Egoz S \& Bowring J 2004; Beyond the romantic and native: The search for a complex ecological aesthetic design language for landscape architecture in New Zealand, Landscape Research, 29(1), pp.57-73.

4. Gedikli R \& Özbilen A 2004; A mathematical model to determine unit area size per person needed in a neigborhood park; a case study in Trabzon city (Turkey), Building and Environment, 39, pp.1365-1378.
5. Gedikli R. 1993; An Investigation on Housing-Garden Relationship in Traditional Residences of Trabzon City, Faculty of Sciences, KTÜ, Graduate Thesis, Trabzon.

6. Thwaites K, Helleur E, Simkins M. 2005; Restorative urban open space: Exploring the spatial configuration of human emotional fulfilment in urban open space, Landscape Research, 30(4), pp.525-547.

7. Tzoulas K, Korpela K, Venn S, Yli-Pelkonen V, Kazmierczak A, Niemela J, James P 2007; Promoting ecosystem and human health in urban areas using Green Infrastructure: A literature review, Landscape and Urban Planning, 81(3), pp.167-178.

8. Barbosa O, Tratalos J.A, Armsworth P.R, Davies R.G, Fuller R.A, Johnson P, Gaston K.J 2007; Who benefits from access to gren space? A case study Sheffield, UK, Landscape and Urban Planning, 83(2), pp.187-195. 
9. Kim M.H, Cho T.B, Kim K.H. 2008; Residents attitudes to landscape and ecology of idyllic housing sites: The case of South Korea, Landscape Research, 33(4), pp.487-501.

10. Cavia R, Cueto G.R, Suarez O.V 2009; Changes in rodent communities according to the landscape structure in an urban ecosystem, Landscape and Urban Planning, 90(1), pp.1-19.

11. Westover T.N 1989; Perceived crowding in recreational setting, Environmental and Behavior, 21(3), pp.258-276.

12. Simonds J.O 1994; Garden cities 21, creating a livable urban environment, Mc Graw-Hill, New York.

13. Hillman J. 1994; The role of urban parks, Findings of the Symposium Church House Conference Centre, pp.6-7, London.

14. Ribe R.G 2005; Aesthetic perceptions of gren-tree retention harvests in vista views, Landscape and Urban Planning, 81(3), pp.167-178.

15. Yang J, Zhao L, Mcbride J 2009; Can you see gren? Assessing the visibility of urban forests in cities, Landscape and Urban Planning, 91(2), pp.97-104.

16. Colding J 2007; Ecological land-use complementation for building resilience in urban ecosysyems, Landscape and Urban Planning, 81(1), pp.46-55.

17. Swensen G, Jerpasen G.B 2008; Cultural heritage in suburban landscape planning, Landscape and Urban Planning, 87(4), pp.289-300.

18. Yang B.E, Brown T.J 1982; A cross-cultural comparaison of preferences for landscape styles and landscape elements, Environment and Behavior, 24, pp.471-507.

19. Burel F, Baudry J 1995; Social, aesthetic and ecological aspects of hedgerows in rural landscapes as framework for greenways, Landscape and Urban Planning, 33(1), pp.327340

20. Bhatti M, Church A 2004; Home, the culture of nature and meanings of gardens in late moderniy, Housing Studies, 19(1), pp.37-51.

21. Syme G.J, Shao Q, Po M., Campbell E 2004; Predicting and understanding home garden water use, Landscape and Urban Planning, 68(1), pp.121-128.

22. Freestone R, Nichols D 2004; Realising new leisure opportunities for old urban parks: The internal reserve in Australia, Landscape and Urban Planning, 68(1), pp.109-120.

23. Rogge E, Neves F, Gulinck H 2007; Perception of rural landscapes in Flanders: Looking beyond aesthetics, Landscape and Urban Planning, 82(4), pp.159-174.

24. Jim C.Y 1998; Old stone walls as an ecological habitat for urban trees in Hong Kong, Landscape and Urban Planning, 42(1), pp.29-43.

25. Gedikli R, Çakıroğlu B 2003; The investigation and preservation of cultural values exist in historical texture through the example of the city Trabzon, II.International City Furniture Symposium \& Exhibition, İSTON, 24-27 April, İstanbul.

26. Ong B.L 2003; Green plot ratio: an ecological measure for architecture and urban planning, Landscape and Urban Planning, 63(4), pp.197-211.

27. Po E, Moreno E, Guardia J, Iniguez L 2002; Identity, quality of life and sustainability in an urban suburb of Barcelona: Adjustment to the city-identity-sustainability network structural model, Environment and Behavior, 34, pp.67-80.

28. Walsh K 2008; Mediterranean landscape archaeology: Marginality and the culture-nature divide, Landscape Research, 33(5), pp.547-564.

29. Bhatti M, Church A 2000; I never promised you a rose garden: gender, leisure and home making, Leisure Studies, 19 (3), pp.183-197.

30. Kenneth G 2007; Japan and China 1: A first attempt at explaining the numerical discrepancy between Japanese style gardens outside Japan and Chinese style gardens outside China, Landscape Research, 32(2), pp.117-146.

31. Janssen J, Knippenberg L 2008; The heritage of the productive landscape: Landscape design for rural areas in the Netherlands, 1954-1985, Landscape Research, 33(1), pp.128 .
32. Taylor K 2009; Cultural Landscape and Asia: Reconciling International and Southeast Asian Regional Values, 34(1), pp.7-31

33. Antrop M 2004; Landscape change and the urbanization process in Europe, 67 (1), pp. 9-26.

34. Van Eetvelde V, Antrop M. 2004; Analyzing structural and functional changes of traditional landscape-two examples from Southern Frances, Landscape and Urban Planning, 67(1), pp.79-95.

35. Turner S 2006; Historic landscape characterisation: A landscape archaeology for research, management and planning, Landscape Research, 31(4), pp.385-389.

36. He J.J, Jia B 2007; Sustainable residential landscapes: A case study in Guangzhou, China, Landscape Research, 32(2), pp.241-254.

37. Vileniske I.G 2008; Influence of built heritage on sustainable development of landscape, Landscape Research, 33(4), pp.425-437.

38. Perry T, Nawaz R 2008; An investiqation into the extent and impacts of hard surfacing of domestic gardens in an area of leeds, United Kinqdom, Landscape and Urban Planning, 86(1), pp.1-13.

39. Jim C.Y, Chen W.Y 2009; Value of scenic views: Hedonic assessment of private housing in Honq Konq, Landscape and Urban Planning, 91(4), pp.226-234

40. Kalın A, Gedikli R, Pulatkan M, Acar C 1999; Formal aesthetic characteristics of unique natural landscape as showing difference from its own geography: An assasment for Turkey, Our Visual Landscape Conference, 23-27 August, Ascona, Switzerland.

41. Ryan R.L 2005; Exploring the effects of environmental experience on attachment to urban natural areas, Environment and Behavior, 37, pp.3-42.

42. Dincyurek O, Mallick H, Numan I 2003; Cultural and environmental values in the arcaded Mesaorian houses of Cyprus, Building and Environment, 38(12), pp.1463-1473. 